\title{
CUGBP Elav-Like Family Member 2
}

National Cancer Institute

\section{Source}

National Cancer Institute. CUGBP Elav-Like Family Member 2. NCI Thesaurus. Code C104686.

CUGBP Elav-like family member $2(508 \mathrm{aa}, \sim 54 \mathrm{kDa}$ ) is encoded by the human CELF2 gene. This protein plays a role in both heart contraction and RNA processing. 